\title{
EFFECTS OF EXERCISE ON PHYSICAL FITNESS AND ANTHROPOMETRIC VARIABLES IN EX-CRACK COCAINE USERS
}

\author{
EFECTOS DEL EJERCICIO SOBRE LA APTITUD FÍSICA Y LAS VARIABLES ANTROPOMÉTRICAS \\ EN LOSEX-USUARIOS DE CRACK
}

Jéssica Abatti Martins' ${ }^{1}$

(Profissional de Educação Física)

Ana Maria Volpato'

(Profissional de Educação Física)

Vanise dos Santos Ferreira Viero' (Profissional de Educação Física)

Antonio Jose Grande²

(Profissional de Educação Física)

Leonardo Roever ${ }^{3}$ (Fisioterapeuta)

Joni Márcio de Farias ${ }^{1}$

(Profissional de Educação Física)

1. Universidade do Extremo Sul Catarinense (UNESC), Grupo de

Pesquisa e Estudo da Promoção da Saúde, Criciúma, SC, Brazil.

2. Universidade do Extremo Sul de

Santa Catarina (UNESC), Laboratório de Prática Baseada em Evidências,

Criciúma, SC, Brazil.

3. Universidade Federal de Uberlândia, Departamento de Pesquisa Clínica, Uberlândia, MG, Brazil.

\section{Correspondence:}

Jéssica Abatti Martins

Universidade do Extremo Sul

Catarinense (UNESC),

Av. Universitária, № 1105, Bairro

Universitário, Criciúma, SC, Brazil. 88806-000.

jessicaabatti@outlook.com

\begin{abstract}
Introduction:Worldwide cocaine use in all its various forms is increasing; cocaine users exceeded 17 million in the world. In Brazil, this data is also alarming. A survey conducted in 2010 found that the country has more than 900,000 crack-cocaine users. Objective: To evaluate the effects of exercise on anthropometric variables and components of physical fitness in ex-crack cocaine users. Methods: Randomized controlled trial with 20 men, divided into exercise group $(n=10)$ and control group $(n=10)$, admitted to a detoxification center. We assessed the physical fitness components related to health (cardiorespiratory endurance, flexibility, muscular strength/endurance, and body composition) before and after the physical training program. Results: The exercise contributed to the maintenance of anthropometric variables, while the control group had an increased in total body fat and visceral fat. Regarding physical fitness, resistance training led to the increase of most variables studied, particularly strength and cardiorespiratory capacity. On the other hand, the $\mathrm{VO}_{2}$ max and the strength of the sedentary subjects were reduced $(\mathrm{P}<0.05)$. Conclusion: The exercise showed beneficial effects on the components of physical fitness and maintenance of body composition.
\end{abstract}

Keywords: crack cocaine; exercise; physical fitness; anthropometry.

\section{RESUMO}

Introdução: O consumo mundial de cocaína em suas diversas formas está aumentando; os usuários de cocaína ultrapassaram 17 milhões no mundo. No Brasil, esses dados também são alarmantes. Uma pesquisa realizada em 2010 descobriu queo país tem mais de 900.000 usuários crack. Objetivo: Avaliar os efeitos do exercício em variáveis antropométricas e componentes de aptidão física em ex-usuários de crack. Métodos: Estudo randomizado e controlado com 20 homens, divididos em grupo exercício $(n=10)$ e grupo controle $(n=10)$, internados em clínica de desintoxicação. Foram avaliados os componentes da aptidão física relacionados à saúde (resistência cardiorrespiratória, flexibilidade, força/resistência muscular e composição corporal) antes e depois do programa de treinamento físico. Resultados: Oexercício contribuiu para a manutenção de variáveis antropométricas, enquanto o grupo controle teve aumento da gordura corporal total e da gordura visceral. Com relação à aptidão física, o treinamento de resistência contribuiu para o aumento da maioria das variáveis estudadas, particularmente força e capacidade cardiorrespiratória. Por outro lado, o VO2max e a força dos sujeitos sedentários foram diminuídos $(P<0,05)$. Conclusão: Oexercício mostrou efeitos benéficos nos componentes da aptidão física en a manutenção da composição corporal.

Descritores: cocaína crack; exercício; aptidão física; antropometria.

\section{RESUMEN}

Introducción: El consumo mundial de cocaína en sus diversas formas está aumentando; los usuarios de cocaína superaron los 17 millones en el mundo. En Brasil, estos datos también son alarmantes. Una encuesta realizada en 2010 encontró que el país tiene más de 900.000 usuarios de crack. Objetivo: Evaluar los efectos del ejercicio en variables antropométricas y componentes de aptitud física en ex-usuarios de crack. Métodos: Estudio aleatorizado y controlado con 20 hombres, divididos en grupo ejercicio $(n=10)$ y grupo control $(n=10)$, internados en una clínica de desintoxicación. Se evaluaron los componentes de la aptitud física relacionados con la salud (resistencia cardiorrespiratoria, flexibilidad, fuerza/resistencia muscular y composición corporal) antes y después del programa de entrenamiento físico. Resultados: El ejercicio contribuyó al mantenimiento de variables antropométricas, mientras que el grupo control tuvo aumento de la grasa corporal total y la grasa visceral. Con respecto a la aptitud física, el entrenamiento de resistencia contribuyó al aumento de la mayoría de las variables estudiadas, sobre todo fuerza y capacidad cardiorrespiratoria. Por otra parte, el VO2máxy la fuerza de los sujetos sedentarios disminuyeron $(P<0,05)$. Conclusión: El ejercicio mostró efectos beneficiosos en los componentes de la aptitud física y en el mantenimiento de la composición corporal.

Descriptores: cocaína crack; ejercicio; aptitud física; antropometría. 


\section{INTRODUCTION}

World consumption of cocaine in its various forms is increasing, cocaine users has passed 17 million in the world. In Brazil, this data is also alarming, a survey done in 2010 found that the country has more than 900,000 crack-cocaine users ${ }^{1}$. In this sense, the National Confederation of Brazilian Municipalities interviewed the health secretaries of all municipalities in the country, and noted that in $98 \%$ of cities surveyed there were problems related to crack-cocaine, including those with less than 20,000 inhabitants ${ }^{1-2}$

The effects of crack-cocaine use, including social and health disorders, which are currently considered a public health problem ${ }^{3}$. Specifically, we highlight the following changes: pulmonary complications, auditory hallucinations, hyperacusis, increased risk of STDs (Sexually Transmitted Diseases), hepatic and renal disorders, deficits in cognitive functions ${ }^{4}$.

Furthermore, the occurrence of changes in body composition is also reported in drug users ${ }^{5}$. The loss of lean body mass, specifically muscles, is common in cocaine users, and also alcohol poisoning via carbon monoxide, and one of its main sources of production is smoking ${ }^{6}$. Regarding fat mass, Balbinot et al $(2011)^{7}$ shows lower percentage of total fat mass in comparison with what is recommended by the literature. This factor is usually associated with cardiovascular disease. Low Body Mass Index (BMI) is associated to severe paranoid disorders induced by cocaine in subjects with secondary anorexia caused by the consumption of this substance ${ }^{8}$. The important relationship between desirable body composition, health and overall well-being.

Literature reports behavioral effects such as the reduction of anxiety and depressive symptoms in this population ${ }^{9}$. Specifically, the recent study showed a decrease of anger, confusion, depression, fatigue and tension in drug addicts after physical activity. Likewise, the physical training focusing on muscular strength and resistance and aerobic activities provided decreased depression and tension. Although, the information of how this occurs and the most effective training to achieve physical and behavioral goals remain obscure. Godfrey et al. (2003) ${ }^{10}$ suggest participation of anabolic hormones such as growth hormone as a mediator of the effects on health and well-being, which is released, among other situations, in high intensity and short duration exercise, such as resistance training.

Many papers describe resistance training as synonymous with strength training, performed in opposition to a given force that imposes resistance through body weight or with the aid of machines or free weights. Therefore, the starting point on resistance training in this population will be considered the opposition to force with their own body weight and with the aid of free weights as a training method.

The role of exercise as an adjunct therapy to psychiatric treatment is well recognized in the scientific community. However, exercise contribution on the health aspects of crack-cocaine users remain an unknown field of research. Thus, this study aimed to investigate the effects of resistance exercise on the anthropometric parameters and components of physical fitness in ex-crack cocaine users.

\section{METHODS}

This study is characterized as randomized controlled trial conducted with institutionalized ex-crack users, was approved by the Research Ethics Committee of the Universidade do Extremo Sul Catarinense under protocol 704.764 on 01/07/2014.

The institution had 110 men, ex-drug users admitted for detoxification. Inclusion criteria used were: the obligation to point out the use of crack as the primary reason for admission, have made the use of this substance for a minimum of six months, in addition to a predicted time of hospital stay equal of greater than 90 days.
Applying the inclusion criteria and considering the interest in participating in the trial, 20 ex-crack cocaine users were included. All participants were informed about the research objectives and signed the Informed Consent Form (ICF). The division of the groups was randomized by drawing lots using shredded paper and plastic bag led by senior researcher, thus maintaining the allocation concealed. The groups were divided as G1 (exercise group, $\mathrm{n}=10$ ) and $\mathrm{G} 2$ (control group, $\mathrm{n}=10$ ).

The exercise was prescribed as recommended by the American College Sports Medicine, which include one to two exercise for each muscle group: shoulder, arms, chest, back, hips, legs and abdomen and we also supervised stretching after the exercise sessions.

Participants were evaluated by a semi-structured questionnaire, developed by the research team, which contained medical, sociocultural, socioeconomic information, Brazilian Association of Research Companies (Abep) 2015, health status and history of drug abuse, carried out in two stages, before and after the exercise intervention.

To assess physical fitness, specific tests were established. For anthropometry: body weight $(\mathrm{kg})$ and height $(\mathrm{cm})$ measurements, a digital scale Filizola of up to $200 \mathrm{~kg}$ was used. The percentage of total Body Fat (\%BF), Fat Body Mass (GCM-kg), Body Mass Index (BMI-Kg/m²) and Lean Body Mass (LBM-kg), was performed by bioelectrical impedance (Bodystat brand analyzer). Waist/Hip Ratio (WHR) was measured through the perimeter of waist and hip ${ }^{5}$.

The assessment of cardiorespiratory capacity $\left(\mathrm{VO}_{2 \text { max }}\right.$.) was measured using Queen's College Step test ${ }^{11}$. The muscular force/resistance test used was the maximum repetitions of abdominal and arm flexion and extension in one minute. Abdominal test followed the protocol having supine position to start the test. The test was performed indoors on a non slippery rubber mat. The length of the jump was assessed $(\mathrm{cm})$ from the starting line to the heel that was closest to the starting line ${ }^{12}$.

Lumbar Traction was performed using dynamometer Takei. The test was carried out semi-inflected trunk legs and arms outstretched. For the handgrip test was used Jamar dynamometer. In a standing position, the participant gripped the dynamometer with one hand and extended his. Trunk flexibility was tested by the sit and reach test. Using a standard sit and reach test box, with palms down, the participant reached forwards ling hands along the measuring scale as far as possible without bending the knee of the extended leg ${ }^{13}$.

The characterization of data was described using absolute and relative frequencies. The values regarding anthropometric variables and the components of physical fitness were assessed for normality using the Kolmogorov-Smirnov test. After verification of normality, comparisons between groups and within groups were made using the unpaired and paired t test, respectively. All tests were performed using the SPSS statistical package (20.0) adopting the significance level of $5 \%(P \leq 0,05)$.

The exercise program applied in G1 was conducted over three months, the frequency of three times a week, totaling 36 sessions. The prescription of 3 sets of 15 to 20 repetitions for each exercise was used in the intensity of $60 \%$ of maximum force assessed by submaximal strength test, for the exercises that used free weights and for the exercises that used the body weight the amount of repetitions was considered for prescription. The choice of this training model is due to the place where the study was carried out, which did not have a gym. All the training protocol features are in accordance with the recommendations of the American College of Sports Medicine for healthy subjects ${ }^{14}$. Exercises were supervised and accompanied by a student of the undergraduate course of Physical Education and by the senior research staff at the institution. 


\section{RESULTS}

A total of 20 ex-crack cocaine users were randomized into two groups of equal number. All participants began and finished the study, so there was no loss of follow-up.

In Figure 1, it is demonstrated how a sample was selected and its allocation according to the groups determined for the study.

Table 1 describes the characteristics of the participants with the following information: age, marital status, economic status, occupation, crack cocaine usage time, tobacco and other substances. These data were stratified according to indicators established by literature, divided in G1 (Exercise) and G2 (control) and distributed by absolute (F) and relative (\%) frequency. The data had normal distribution for both groups.

Table 2 shows the values of anthropometric variables (weight, BMI, body fat percentage, fat mass, lean body mass and waist-hip ratio) and physical fitness and health (flexibility, strength of upper limbs, lower limb strength, abdominal strength, handgrip strength, back strength and analysis of VO2max) comparison between in the baseline G1 and G2. The results are presented as means and confidence interval (CI) 95\%. The variables compared in the baseline showed no significant difference using t test. Just flexibility show statistical difference $(p \leq 0,05)$.

The Table 3 show dates comparison between groups post-intervention the variables anthropometrics and physical fitness. The results are presented as means, confidence interval (CI) 95\%, mean difference (MD) and value $P$.

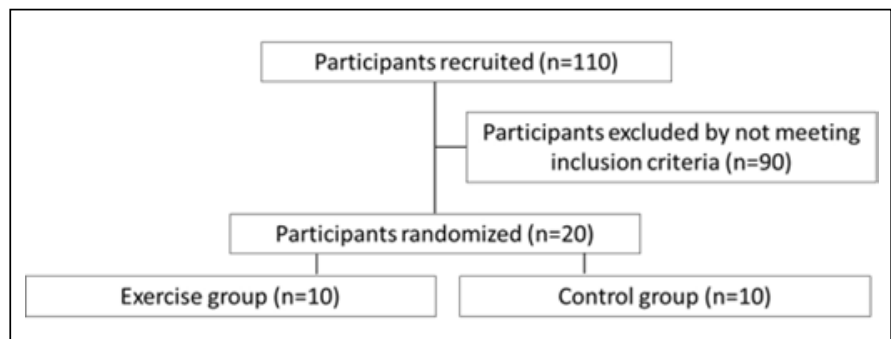

Figure 1. Selection and division of the sample.

Table 1. Characterization of participants.

\begin{tabular}{|c|c|c|c|c|c|c|}
\hline \multirow{2}{*}{ Variables } & & \multicolumn{2}{|c|}{ Exercise (G1) } & \multicolumn{2}{|c|}{ Control (G2) } & \multirow{2}{*}{$P$ value } \\
\hline & & $F$ & $\%$ & $F$ & $\%$ & \\
\hline \multirow{3}{*}{ Age groups (years) } & 12 to 18 & 5 & 50 & 3 & 30 & 0.42 \\
\hline & 18 to 35 & 3 & 30 & 4 & 40 & 0.36 \\
\hline & Over 35 & 2 & 20 & 3 & 30 & 0.26 \\
\hline \multirow{3}{*}{ Estado Civil } & Single & 10 & 100 & 5 & 50 & 0.83 \\
\hline & Divorced & 0 & 0 & 2 & 20 & 0.20 \\
\hline & Married & 0 & 0 & 3 & 30 & 0.30 \\
\hline \multirow{5}{*}{ Economic level } & B1 & 3 & 30 & 0 & 0 & 0.30 \\
\hline & B2 & 2 & 20 & 2 & 20 & 0.50 \\
\hline & $\mathrm{C} 1$ & 3 & 30 & 3 & 30 & 0.50 \\
\hline & $\mathrm{C} 2$ & 1 & 10 & 3 & 30 & 0.25 \\
\hline & D & 1 & 10 & 2 & 20 & 0.12 \\
\hline \multirow{2}{*}{ Employed } & Yes & 6 & 60 & 7 & 70 & 0.65 \\
\hline & No & 4 & 40 & 3 & 30 & 0.36 \\
\hline \multirow{3}{*}{$\begin{array}{c}\text { Crack-cocaine time } \\
\text { of use (years) }\end{array}$} & Up to 1 & 4 & 40 & 4 & 40 & 0.50 \\
\hline & 1 to 2 & 2 & 20 & 1 & 10 & 0.17 \\
\hline & Over 2 & 4 & 40 & 5 & 50 & 0.45 \\
\hline \multirow{2}{*}{ Smoking } & Yes & 10 & 100 & 10 & 100 & 0.50 \\
\hline & No & 0 & 0 & 0 & 0 & \\
\hline \multirow{3}{*}{$\begin{array}{l}\text { Substance used } \\
\text { additionally to } \\
\text { crack-cocaine }\end{array}$} & Nicotine & 10 & 100 & 10 & 100 & 0.50 \\
\hline & Alcohol & 9 & 90 & 1 & 100 & 0.91 \\
\hline & Cannabis & 9 & 90 & 9 & 90 & 0.50 \\
\hline
\end{tabular}

Source: research data. $\mathrm{F}=$ absolute frequency, $\%=$ relative frequency.
Table 2. Comparison between groups for anthropometric and physical fitness variables - baseline.

\begin{tabular}{|c|c|c|c|}
\hline Variables & $\begin{array}{c}\text { G } 1 \\
(\mathrm{X}-\mathrm{Cl} 95 \%)\end{array}$ & $\begin{array}{c}\text { G } 2 \\
(\mathrm{X}-\mathrm{Cl} 95 \%)\end{array}$ & $P$ value \\
\hline Weight (kg) & $\begin{array}{c}67.51 \\
(58.88-76.13) \\
\end{array}$ & $\begin{array}{c}75.92 \\
(60.57-91.26)\end{array}$ & 0.294 \\
\hline $\mathrm{BMI}(\mathrm{kg}, \mathrm{m} 2)$ & $\begin{array}{c}23.29 \\
(21.21-25.36\end{array}$ & $\begin{array}{c}26.08 \\
(21.88-30.27)\end{array}$ & 0.195 \\
\hline$\%$ Fat & $\begin{array}{c}11.55 \\
(7.47-15.62) \\
\end{array}$ & $\begin{array}{c}16.85 \\
(12.39-21.30) \\
\end{array}$ & 0.063 \\
\hline FM (kg) & $\begin{array}{c}8.26 \\
(4.50-12.01)\end{array}$ & $\begin{array}{c}13.58 \\
(7.22-19.93)\end{array}$ & 0.121 \\
\hline LM (kg) & $\begin{array}{c}59.25 \\
(53.40-65.09)\end{array}$ & $\begin{array}{c}62.34 \\
(52.15-75.52)\end{array}$ & 0.559 \\
\hline WHR (cm) & $\begin{array}{c}0.87 \\
(0.84-0.89)\end{array}$ & $\begin{array}{c}0.89 \\
(0.82-0.95)\end{array}$ & 0.628 \\
\hline Flexibility & $\begin{array}{c}29.40 \\
(24.35-34.44) \\
\end{array}$ & $\begin{array}{c}20.90 \\
(14.76-27.03) \\
\end{array}$ & $.026^{*}$ \\
\hline UL strength & $\begin{array}{c}18.40 \\
(12.79-24.0)\end{array}$ & $\begin{array}{c}18 \\
(8.45-27.55)\end{array}$ & 0.936 \\
\hline LL strength, & $\begin{array}{c}169.60 \\
(153.76-185.43)\end{array}$ & $\begin{array}{c}168.80 \\
(132.08-205.51)\end{array}$ & 0.964 \\
\hline Abdominal strength & $\begin{array}{c}22.10 \\
(18.40-25.79) \\
\end{array}$ & $\begin{array}{c}19.40 \\
(13.01-25.78) \\
\end{array}$ & 0.419 \\
\hline Handgrip strength & $\begin{array}{c}41.50 \\
(38.15-44.84) \\
\end{array}$ & $\begin{array}{c}40.40 \\
(35.02-45.77)\end{array}$ & 0.699 \\
\hline Back strength & $\begin{array}{c}130.60 \\
(112.64-148.55) \\
\end{array}$ & $\begin{array}{c}114.20 \\
(83.48-144.91) \\
\end{array}$ & 0.311 \\
\hline VO2 max & $\begin{array}{c}48.19 \\
(44.88-51.49)\end{array}$ & $\begin{array}{c}46.14 \\
(43.18-49.09)\end{array}$ & 0.31 \\
\hline
\end{tabular}

Source: research data. BMI (Body mass index), MCG (Fat Mass), LM (Lean mass), WHR (Waist-hip ratio), UL strength (Upper Limb strength), LL (Lower limb strength), $\mathrm{VO}_{2}$ (Maximum Oxygen uptake).

Table 3. Comparison between groups post-intervention for anthropometric and physical fitness variables - baseline.

\begin{tabular}{|c|c|c|c|c|}
\hline Variável & $\begin{array}{c}\mathrm{G} 1 \\
(\mathrm{X}-\mathrm{Cl} 95 \%)\end{array}$ & $\begin{array}{c}\text { G } 2 \\
\text { (X-Cl 95\%) }\end{array}$ & $\begin{array}{c}\text { MD } \\
(\mathrm{X}-\mathrm{Cl} 95 \%)\end{array}$ & Valor $p$ \\
\hline Weight (kg) & $\begin{array}{c}68.30 \\
(60.06-76.53)\end{array}$ & $\begin{array}{c}76.02 \\
(61.1-90.8)\end{array}$ & $\begin{array}{c}-7.72 \\
(-22.43-6.99)\end{array}$ & 0.317 \\
\hline BMI $(k g, m 2)$ & $\begin{array}{c}23.57 \\
(21.43-25.70)\end{array}$ & $\begin{array}{c}26.09 \\
(22.18-29.99)\end{array}$ & $\begin{array}{c}-2.52 \\
(-6.37-1.33)\end{array}$ & 0.217 \\
\hline$\%$ Fat & $\begin{array}{c}9.99 \\
(6.39-13.58)\end{array}$ & $\begin{array}{c}19.78 \\
(16.25-23.30)\end{array}$ & $\begin{array}{c}-9.79 \\
(-14.15--5.42)\end{array}$ & $.000^{*}$ \\
\hline FM (kg) & $\begin{array}{c}7.21 \\
(3.79-10.62)\end{array}$ & $\begin{array}{c}15.62 \\
(10.32-20.91)\end{array}$ & $\begin{array}{c}-8.41 \\
(-13.86--2.95)\end{array}$ & $.007^{*}$ \\
\hline LM (kg) & $\begin{array}{c}60.99 \\
(55.36-66.61)\end{array}$ & $\begin{array}{c}60.40 \\
(50.24-70.65)\end{array}$ & $\begin{array}{c}0.59 \\
(-9.47-10.65)\end{array}$ & 0.91 \\
\hline WHR (cm) & $\begin{array}{c}0.85 \\
(0.83-0.86)\end{array}$ & $\begin{array}{c}0.89 \\
(0.82-0.95)\end{array}$ & $\begin{array}{c}-0.04 \\
(-0.09-0.01)\end{array}$ & 0.205 \\
\hline Flexibility & $\begin{array}{c}37.30 \\
(31.37-43.22)\end{array}$ & $\begin{array}{c}20.40 \\
(14.06-26.73)\end{array}$ & $\begin{array}{c}16.90 \\
(9.38-24.41)\end{array}$ & $0.000^{*}$ \\
\hline UL strength & $\begin{array}{c}26 \\
(21.02-30.97)\end{array}$ & $\begin{array}{c}15 \\
(5.28-24.71)\end{array}$ & $\begin{array}{c}11.00 \\
(1.54-20.45)\end{array}$ & 0.035 \\
\hline LL strength, & $\begin{array}{c}190.10 \\
(172.28-207.91)\end{array}$ & $\begin{array}{c}164.20 \\
(130.52-197.87)\end{array}$ & $\begin{array}{c}25.90 \\
(-7.10-58.90)\end{array}$ & 0.141 \\
\hline $\begin{array}{l}\text { Abdominal } \\
\text { strength }\end{array}$ & $\begin{array}{c}29.30 \\
(25.42-33.17)\end{array}$ & $\begin{array}{c}16.40 \\
(11.20-21.59)\end{array}$ & $\begin{array}{c}12.90 \\
(7.28-18.51)\end{array}$ & 0.0003 \\
\hline Handgrip strength & $\begin{array}{c}46.90 \\
(43.65-50.04)\end{array}$ & $\begin{array}{c}40.60 \\
(34.79-46.40)\end{array}$ & $\begin{array}{c}6.30 \\
(0.58-12.01)\end{array}$ & $0.044^{*}$ \\
\hline Back strength & $\begin{array}{c}137.10 \\
(118.06-156.13) \\
\end{array}$ & $\begin{array}{c}111.50 \\
(85.16-137.83)\end{array}$ & $\begin{array}{c}25.60 \\
(-2.55-53.75)\end{array}$ & 0.091 \\
\hline VO2 max & $\begin{array}{c}57.02 \\
(49.38-64.65)\end{array}$ & $\begin{array}{c}42.56 \\
(39.97-45.14)\end{array}$ & $\begin{array}{c}14.46 \\
(7.47-21.44)\end{array}$ & $0.000^{*}$ \\
\hline
\end{tabular}

Source: research data. BMI (Body mass index), MCG (Fat Mass), LM (Lean mass), WHR (Waist-hip ratio), UL strength (Upper Limb strength), LL (Lower limb strength), $\mathrm{VO}_{2}$ (Maximum Oxygen uptake). 


\section{DISCUSSION}

In general, there is consistent evidence in recent decades that regular exercise improves physical fitness and promote the reduction of mortality in the adult population ${ }^{15}$. The various methods of exercises, improving physical fitness and physical activity are related to prevention, with the rehabilitation of diseases and the quality of life However, there are few studies regarding the prescription of exercise in the population of former crack users, primarily related to business body composition and physical fitness related to health. Our results indicate that there was a beneficial effect of training in relation to physical fitness, and anthropometric variables.

The investigated group comprised by men, mostly singles (only 30\% married) and adults. Crack-cocaine users' profile was first investigated in 1989, demonstrating that use was made mostly by men younger than 30, unemployed, with low purchasing power and education ${ }^{16}$. Similarly, Health Surveys published later portray higher percentage of use in males ${ }^{17}$. The majority of the sample investigated in this study reported being employed, a result that differs from other researches that users are mostly unemployed or without formal work bond ${ }^{18}$.

The socioeconomic classification of ex-crack cocaine users of this study indicate that 15\% are situated in the economic level B1, 20\% in the B2, 30\% in the C1 and 20\% in the C2, and 15\% in the D. In other words, most users belong to economic level $\mathrm{C} 1$ and a minority is concentrated in the level D. The research that characterize the crack cocaine users profile emphasize increased consumption in poor and marginalized populations with compulsive pattern of drug use and placed in problematic environments ${ }^{19}$.

Regarding the time of use, both groups reported the use of other substances during hospitalization (100\% use tobacco) and even before hospitalization, $90 \%$ associated the crack cocaine with marijuana. According to the literature, the crack cocaine users are generally poly users, considering the fact that most start addiction to other drugs as well as maintains the concurrent use of other psychoactive substances to crack cocaine use. Similar to the results found in this study, alcohol and tobacco are the legal drugs consumed before the start of crack cocaine use, while marijuana is the illicit substance used by the users before starting the consumption of crack-cocaine ${ }^{4}$.

Considering the anthropometric variables in this investigation, in the pre-intervention, both groups show similarities in the measurement, which reflects the homogeneity of the sample. In addition, BMI values are in the ideal weight range or slightly overweight, while body composition is within normal standards in the sample ${ }^{5}$. Importantly, changes in BMI in cocaine users are associated with severe paranoid disorders, especially in anorexic users ${ }^{8}$.

It is known that the central effects caused by drug use can directly affect the control centers of hunger to satiety, causing decreased appetite. Cocaine, for example, reduces the action of neuropeptide $Y$, one of hypothalamic stimulators feeling of hunger ${ }^{20}$. In contrast, users in treatment present significant increase in the percentage of fat and fat mass ${ }^{2}$, similar to what was observed in this study. These observations may be related to dysfunctional eating patterns in individuals in recovery from drug addiction ${ }^{21}$, such as eating foods low in essential nutrients ${ }^{22}$. The excess intake followed by abstinence can be a mechanism for reestablishing the neurotransmitters (serotonin and dopamine mainly) of reward system during recovery of drug users ${ }^{23}$. It is known that excess weight and increasing the amount of body fat contributes as a risk factor for chronic diseases, especially for diabetes, hypertension, hypercholesterolemia and hypertriglyceridemia ${ }^{24}$. Therefore, these observations strongly justify the inclusion of effective exercise programs in order to prevent the incidence of metabolic diseases associated with rehabilitation of crack users.

Assessments of physical fitness components in Table 3 indicate great effectiveness of exercise in the population. Comparisons between groups at post-intervention period indicate a beneficial effect of exercise program in improving the strength levels of the upper limbs, flexibility, abdominal strength, handgrip strength, back strength and $\mathrm{VO}_{2}$ max. The effectiveness of exercise is also highlighted when compared to the mean pre and post intervention in the exercise group (Table 4). According to the literature, the intensity of $60 \%$ of maximum force already allows strength gains in its practitioners, which agrees with our results. Moreover, this is the first study that shows the strength gain in this specific population through a prescribed protocol in a controlled manner.

In addition, in comparing pre- and post-intervention of the sedentary group, there was a reduction in upper limb strength, abdominal strength and $\mathrm{VO}_{2}$ max (Table 4). Those results are expected, considering that significant decreases in skeletal muscle mass and force production capacity are widespread problems that typically occur in the face of disu$\mathrm{se}^{25}$. In this context, it is possible that three months of disuse associated with other factors related to the long period of drug use contribute to strength changes in this population.

The population of drug users is at increased risk compared to the adult population that does not use drugs. The noradrenergic and dopaminergic stimulation generated during cocaine intoxication can induce convulsions, cardiac and cerebral ischemia. Regarding mental health, chronic use of cocaine induces psychiatric disorders such as depression, anxiety, panic and schizophrenia. Likewise, intellectual performance is

Table 4. Comparison of intragroup physical fitness components.

\begin{tabular}{|c|c|c|c|c|c|c|c|c|}
\hline \multicolumn{5}{|c|}{ G 1 (X - Cl 95\%) } & \multicolumn{4}{|c|}{ G 2 (X - Cl 95\%) } \\
\hline Physical fitness & Pre-intervention & Post-intervention & MD & $P$ value & Pre-intervention & Post-intervention & MD & $P$ value \\
\hline Flexibility & $\begin{array}{c}29.40 \\
(24.35-34.44) \\
\end{array}$ & $\begin{array}{c}37.30 \\
(31.37 .43 .22) \\
\end{array}$ & $\begin{array}{c}-7.90 \\
(-14.64--1.15) \\
\end{array}$ & $.002^{*}$ & $\begin{array}{c}20.90 \\
(14.72-27.03) \\
\end{array}$ & $\begin{array}{c}20.40 \\
(14.06-26.73) \\
\end{array}$ & $\begin{array}{c}0.50 \\
(-7.02-8.02) \\
\end{array}$ & 0.485 \\
\hline UL strength & $\begin{array}{c}18.40 \\
(12.79-24.00) \\
\end{array}$ & $\begin{array}{c}26 \\
(21.02-30.97) \\
\end{array}$ & $\begin{array}{c}-7.60 \\
(-14.09--1.10) \\
\end{array}$ & $.000^{*}$ & $\begin{array}{c}18 \\
(8.45-27.55)\end{array}$ & $\begin{array}{c}15 \\
(5.28-24.71)\end{array}$ & $\begin{array}{c}3.00 \\
(-8.80-14.80) \\
\end{array}$ & $.045^{*}$ \\
\hline LL strength, & $\begin{array}{c}169.60 \\
(153.76-185.43) \\
\end{array}$ & $\begin{array}{c}190.10 \\
(172.28-207.91) \\
\end{array}$ & $\begin{array}{c}-20.50 \\
(41.15-0.15) \\
\end{array}$ & $.010^{*}$ & $\begin{array}{c}168.80 \\
(132.08-205.51) \\
\end{array}$ & $\begin{array}{c}164.20 \\
(130.52-197.87) \\
\end{array}$ & $\begin{array}{c}4.60 \\
(-38.56-47.76) \\
\end{array}$ & 0.335 \\
\hline Abdominal strength & $\begin{array}{c}22.10 \\
(18.40-25.79)\end{array}$ & $\begin{array}{c}29.30 \\
(25.42-33.17)\end{array}$ & $\begin{array}{c}-7.20 \\
(-11.83--2.56)\end{array}$ & $.000^{*}$ & $\begin{array}{c}19.40 \\
(13.01-25.78)\end{array}$ & $\begin{array}{c}16.40 \\
(11.20-21.59)\end{array}$ & $\begin{array}{c}3.00 \\
(-4.12-10.12)\end{array}$ & $.027^{*}$ \\
\hline Handgrip strength & $\begin{array}{c}41.50 \\
(38.15-44.84) \\
\end{array}$ & $\begin{array}{c}46.90 \\
(43.75350 .04) \\
\end{array}$ & $\begin{array}{c}-5.40 \\
(-9.37--1.42) \\
\end{array}$ & $.003^{*}$ & $\begin{array}{c}40.40 \\
(35.02-45.77) \\
\end{array}$ & $\begin{array}{c}40.60 \\
(34.79-46.40) \\
\end{array}$ & $\begin{array}{c}-0.20 \\
(-43.05--29.34) \\
\end{array}$ & 0.828 \\
\hline Back strength & $\begin{array}{c}130.60 \\
(112.64-148.55)\end{array}$ & $\begin{array}{c}137.10 \\
(118.06-156.13)\end{array}$ & $\begin{array}{c}-6.50 \\
(-29.77-15.57)\end{array}$ & 0.136 & $\begin{array}{c}114.20 \\
(83.48-144.91)\end{array}$ & $\begin{array}{c}111.50 \\
(85.16-137.83)\end{array}$ & $\begin{array}{c}2.70 \\
(-32.35-37.75)\end{array}$ & 0.666 \\
\hline VO2 max & $\begin{array}{c}48.19 \\
(44.88-31.49)\end{array}$ & $\begin{array}{c}57.02 \\
(49.38-64.63)\end{array}$ & $\begin{array}{c}-8.83 \\
(-16.03--1.62)\end{array}$ & .064 & $\begin{array}{c}46.14 \\
(43.18-49.09)\end{array}$ & $\begin{array}{c}42.56 \\
(39.97-45.14)\end{array}$ & $\begin{array}{c}3.58 \\
(0.22-7.01)\end{array}$ & $.000^{*}$ \\
\hline
\end{tabular}

Source: research data. UL strength (Upper Limb strength), LL (Lower limb strength), $\mathrm{VO}_{2}$ (Maximum Oxygen uptake). 
impaired. The effect of crack cocaine use on the respiratory system is also described. Various problems such as cough, sputum, pneumonia, hemoptysis, bronchospasm and pulmonary edema are reported ${ }^{26}$.

The limitations of the research are related to the sample size, small number of participants who met the inclusion criteria, thus increasing the likelihood of selection bias. Due to characteristics of intervention, blinding participants and personnel was not possible.

In this study, we showed evidence that exercise is a powerful intervention to help in the recovery process. The results of this study conclude that strength training program using body weight and exercises with free weights at $60 \%$ of the value of the load tested, during 36 sessions contribute to improving physical fitness and health and maintain anthropometric variables of ex-crack users admitted to rehabilitation clinic. These data justify the incorporation of physical education professional with multidisciplinary teams to contribute both to physical and mental health of crack user. Further studies focusing on modification of physical training methodology and outcomes such as quality of life should be explored.

All authors declare no potential conflict of interest related to this article.

AUTHORS' CONTRIBUTIONS: Each author made significant individual contributions to this manuscript. JAM (0000-0003-0203-0572)* contributed in the design and development of research, analysis and interpretation of data. JAM, AMV (0000-0002-7239-7778)*, AJG (0000-0001-7182-075X)* and JMF (0000-0003-2843-6482)* contributed in writing, critical review of the relevant intellectual content. VSFV (0000-0002-7780-3595)* contributed in the writing, analysis and interpretation of data. LR (0000-0002-75175548)* contributed in critical review of the relevant intellectual content. JMF (0000-0003-2843-6482)* contributed in the design and development of research, analysis and interpretation of data. All authors reviewed and approved the final version of the manuscript. *ORCID (Open Researcher and Contributor ID).

\section{REFERENCES}

1. United Nations Office on Drugs and Crime. World Drug Report 2014. Disponível em: https://www. unodc.org/documents/wdr2014/World_Drug_Report_2014_web.p [acesso em 2014 jun 20]

2. Marques ACP, Ribeiro M, Laranjeira RR, Andrada NC. Abuso e dependência: crack. Rev Assoc Med Bras. 2015;58(2):138-40.

3. Jorge MS, Quinderé PH, Yasui S, Albuquerque RA. Ritual de consumo do crack: aspectos socioantropológicos e repercussões para a saúde dos usuários. Ciênc Saúde Colet. 2013;18(10):2909-18.

4. Balbinot AD, Alves GSL, Amaral Junior AF, Araujo RB. Perfil antropométrico de dependentes de crack hospitalizados para desintoxicação. Rev HCPA \& Fac Med Univ Fed Rio Gd do Sul. 2011;31(3):312.

5. Rezende F, Rosado L, Franceschinni S, Rosado G, Ribeiro R, Marins JC. Revisão critica dos métodos disponíveis para avaliar a composição corporal em grandes estudos populacionais e clínicos. Arch Latinoam Nutr. 2007;57(4):327-4

6. Raposo JN, Joao A, Namora J, Carvalho A. Rabdomiolise - breve revisão: a propósito de um caso. Med Int. 2002;9(1):80-4.

7. Balbinot AD, Alves GSL, do Amaral Jr. AF, Araujo RB. Perfil antropométrico de dependentes de crack hospitalizados para desintoxicação. Revista H. C. P. A.. 2001 b; 31(3): 311-317.

8. Ochoa ACG. Reflexiones sobre el tratamiento de transtornos paranoides inducidos per ló consumo de cocaina. Liberaddictus. 2006;90(1):3-8

9. Chaouloff F. Effects of acute physical exercise on central serotonergic systems. Med Sci Sports Exerc. 1997;29(1):58-62.

10. Godfrey RJ, Madgwick Z, Whyte GP. The exercise-induced growth hormone response in athletes. Sports Med. 2003;33(8):599-613.

11. Chatterjee S, Chatterjee P, Bandyopadhyay A. Cardio respiratory fitness of obese boys. Indian J Physiol Pharmacol. 2005;49(3):353-7.

12. Castro-Piñero J, Ortega FB, Artero EG, Girela-Rejón MJ, Mora J, Sjöström M, et al. Assessing muscular strength in youth: usefulness of standing long jump as a general index of muscular fitness. J Strength Cond Res. 2010;24(7):1810-7.

13. Wells KF, Dillon EK. The sit and reach. A test of back and leg flexibility. Res Quart.1952;23:115-8.
14. American College of Sports Medicine.. American College of Sports Medicine position stand. Progression models in resistance training for healthy adults. Med Sci Sports Exerc. 2009;41(3):687-708.

15. ACSM's Guidelines for Exercise Testing and Prescription. 6th ed. Philadelphia: Lippincott Williams \& Wilkins; 2000.

16. Nappo SA, Galduróz JCF, Noto AR. Crack use in São Paulo. Subst Use Misuse. 1996;31(5):565-79.

17. Carlini AE, Galduróz JCF, Noto AR, Nappo SA. II levantamento domiciliar sobre o uso de drogas psicotrópicas no Brasil: estudo envolvendo as 108 maiores cidades do país: 2005. São Paulo: Centro Brasileiro de Informações Sobre Drogas Psicotrópicas (Cebrid), Universidade Federal de São Paulo (Unifesp); 2005.

18. Oliveira LG, Nappo SA. Crack na cidade de São Paulo: acessibilidade, estratégias de mercado e formas de uso. Rev Psiquiatr Clín. 2008;35(6):212-8.

19. Ferreira FOF, Turchi MD, Laranjeira R, Castelo A. Perfil sociodemográfico e de padrões de uso entre dependentes de cocaína hospitalizados. Rev Saude Publica. 2003;37(6):751-9.

20. Wahlestedt C, Karoum F, Jaskiw G, Wyatt RJ, Larhammar D, Ekman R, et al. Cocaine-induced reduction of brain neuropeptide Y synthesis dependent on medial prefrontal cortex. Proc Natl Acad Sci U S A. 1991;88(6):2078-82

21. Hatcher AS. Weight matters during recovery: unhealthy eating behaviors can impede client progress. Addiction Professional. 2004;2 (6):23-4.

22. Ribeiro LA, Sanchez ZM, Nappo SA. Surving crack: a qualitative study of strategies and tactics developed by Brazilian users to deal with the risks associated with drug. BMC Public Health. 2010;10:671-81.

23. Gold MS. From bedside to bench and back again: a 30-year saga. Physiol Behav. 2011;104(1):157-61.

24. Rezende FAC, Rosado LEF, Franceschinni SCC, Rosado GP, Ribeiro RCL. Aplicabilidade do índice de massa corporal na avaliação da gordura corporal. Rev Bras Med Esporte. 2010;16(2):90-4.

25. Berg HE, Dudley GA, HaggmarkT, Ohlsen H, Tesch PA. Effects of lower limb unloading on skeletal muscle mass and function in humans. J Appl Physiol. 1991;70(4):1882-85.

26. Gold MS. Cocaine (and crack): clinical aspects. In: Lowinson JH, Ruiz P, Millman RB, Langrod JG, editors. Substance abuse. A comprehensive textbook. 3rd ed. Baltimore: Williams \& Willkins; 1997. p. 181-99. 